\title{
Finite Element Analysis of Split Type Header in Air Cooled Heat Exchanger
}

\author{
Mukesh Kumar Singh ${ }^{1}$, Abhishek Jain ${ }^{2}$ \\ Department of Mechanical Engineering, Barkatullah University Institute of Technology Bhopal, India.
}

\begin{abstract}
Split type header is a part of tube bundle of an Air-cooled heat exchanger, used in refinery and oil \& gas production. Typically, header can be considered as a pressure vessel subjected to uniform internal pressure. Hence the header and nozzle in various design and operating conditions needs to be checked and verified for soundness of participating components. Top plate due to uniform internal pressure in the nozzle \& header plate can produce high-localized stress and deformation. If the components are not designed for these conditions, safety of the equipment is at stake. Hence check for the stress and displacement of the header during operating condition is carried out using finite element analysis software and observed that header nozzle is free from collapse and serviceability failure.
\end{abstract}

\section{Introduction}

${ }^{(1)}$ Heat exchangers are systems that transfer heat between fluid mediums. The fluids or gases in a heat exchanger can be mixed or the energy transference can go through a conductive wall that keeps them separate. Air-cooled heat exchangers typically have rectangular bundles containing several rows of tubes. The hot fluid enters at the top of the bundle through nozzle pipe. While air is blown by fans vertically upwards across the tube bank, i.e. counter current flow. Structural integrity of the header box can be checked by using ${ }^{(12)}$ Appendix 13 of ASME Sec VIII Div I and other parts of the exchanger header box with the respective clauses of ASME code. For installing the nozzle on the header box opening is made on it, this opening of the vessel must be reinforced with an equal amount of metal which has been cut out for the opening. The reinforcement may be an integral part of the vessel and nozzle or may be an additional reinforcing pad. In addition the compensation must account for the bending strength as well as the membrane strength. The reinforcement calculations for nozzle openings according to UG-39 are required in addition to bending \& membrane strength. However, the calculation of 'Area required', according to UG-39, requires that the 'required thickness'(tr) be substituted for in the formula, and it has not been calculated, since the method used in Appendix 13 is by assuming a thickness and calculating stresses then comparing with allowable stresses and yield stress. This means that 'required thickness' (tr) cannot be directly calculated. Accordingly, the required area 'A' cannot be directly calculated however in this case nozzle opening is larger than $1 / 2$ of the header opening hence is beyond the scope of UG-39 of ASME Sec VIII Div-I and therefore the calculation has to done by finite element method.

\subsection{About Split Type Header}

Split type header is used where differential temperature between two passes exceeds $111 \mathrm{deg}$ C. Split headers are type of plug headers/tapped cover headers which are made in two different pressure compartments such that each compartment has geometry to allow only one pass of fluid to pass through it. It is used when there is more than one passes in tube bundle. It is mostly rectangular or square in shape and covered by side/end plates. Longer dimension of split header represents tube/plug sheet and shorter dimension represents top/bottom plates. Its dimension $(\mathrm{LxWxH})$ depends upon design pressure, design temperature, corrosion allowance, tube diameter, nozzle diameter, type of tube to tube sheet joint, type of weld between header plates and thickness of stay plates between tube rows. Placement: It is placed on top of other header which remains in direct metal to metal contact. In order to reduce friction between headers, SS plates are welded on both top and bottom headers. It is designed as per ASME Sec VIII Div 1 Mandatory Appendix 13 and API-661. Further differential tube expansion due to header movement is calculated which depends upon operating temperature and metallurgy used.

\subsection{About The Company \\ ${ }^{(3)}$ GEI Industrial Systems Ltd}

was established in the year 1970 in the city of Bhopal in the Central Indian State of Madhya Pradesh. GEI Industrial Systems Ltd is a leader in heat transfer technology for more than 40 years and specializes in the design, manufacture, fabrication, testing, and erection \& commissioning of Air Cooled Heat Exchangers for Oil, Gas and Power sector and Air Cooled Vacuum Steam Condensers for Steam Turbine Power Plants. GEI is an ISO 9001-2008 certified company and follow Quality Management Systems for the entire business process right 
from the basic design to manufacturing and installation at the site. GEI holds $\mathrm{U}$ stamp certification; The National Board of Boilers and Pressure Vessel Inspector have provided R stamp certification and NB Marking. More than 4000 bundles of Air Cooled Heat Exchanger and Air Cooled Steam Condenser are operating in India and abroad in the oil, gas and power sector in more than 18 countries worldwide. GEI heat transfer products are operating across the globe in the regions of Africa, Americas, Asia, Europe and Oceania. GEI is today one of the leading Engineering and Manufacturing Company dealing with heat transfer equipments with a major thrust in Air Cooled Heat Exchangers and Air Cooled Steam Condensers. The Air Cooled Heat Exchangers are used for cooling of hot fluids using atmospheric air in the Oil and Gas Exploration, Production, Refining and Petrochemical Industry and also in the power plants as dry cooling tower as a replacement of conventional wet type cooling towers.

Air Cooled Vacuum Steam Condensers are revolutionary product being used in steam turbine power plants thereby eliminating Water Cooled Steam Condenser and Cooling Towers which consumes lot of water.

${ }^{(3)}$ GEI has a total factory area of about 34.5 acres spread at two locations namely in Govindpura and Mandideep near Bhopal. The total manpower strength of GEI is 650 which include qualified professional and experience workmen trained in various disciplines right from Basic Design, Detailed Design and Engineering, Procurement, Project Monitoring, Production Planning, Manufacturing, Quality Control, Logistics, Site Services and support functional like Finance, HR, Safety and Maintenance.Heat transfer products designed manufactured and supplied by GEI have been installed at different locations around the Globe and are performing satisfactory at different locations in Africa, Europe, Middle East, South East and Far East Asian countries and in the Americas.

\subsection{GEOMETRICAL PARAMETER}

\section{Geometrical, Material Parametres And Design Data}

The 3-Dimensional Shell form model of the Top/Bottom plate of header \& nozzle in corroded condition is considered for loading. The Dimension of the Top/Bottom plate of header is of 90.985 inch length,1.378 inch thickness and width is 8.859 inch. For DN 150 SCH 160 nozzle Pipe circular size 152.4 O/D Thickness $41.3 \mathrm{~mm}$

\subsection{MATERIAL}

The material used is SA 516 Gr.70 for plates and SA 182 Gr. F304/304L for pipe for which material properties are accounted

Allowable stress Sm $=118 \quad \mathrm{~N} / \mathrm{mm} 2$

Modulus of elasticity E = $200.93 \times 103 \mathrm{~N} / \mathrm{mm} 2\left(@ 45^{\circ} \mathrm{C}\right.$ )

Poison's ration $\mu \quad=0.3$

Shear Modulus $\quad=78.48 \times 103 \mathrm{~N} / \mathrm{mm} 2$

Material properties are taken from ASME Sec II-D.

\subsection{DESIGN DATA}

Design code: ASME Section VIII, Div.1, \& API 661.

Design Pressure : 1200 Psi

Design temperature $\quad: \quad 580^{\circ} \mathrm{F}$

Corrosion allowance: $\quad 0$

\section{Finite Element Modeling}

The analysis is performed using finite element analysis computer program. The model is meshed with shell mesh elements, finite element length 10 . Elements have a constant state of strain or stress over the integration domain. Elements are more preferable to accurately capture the variation in the result (stress, strain and displacement) across the part. The model is meshed all over. The thickness of the different mesh of the model is changed to take care of varying thickness of header top plate and nozzle. As the headers top plate and nozzle is analysed for FEA analysis, which is welded on the edge surface of tube sheet, plug sheet \& end plates. So the top plate behaves as a shell member with all its surface edges restrained. ${ }^{(13)}$ The stress evaluation is performed as per Appedix-4 of ASME Code Section VIII, Div 2, Ed2004 addenda 2006 at pressure max. 1200psi.The primary and primary plus secondary stress intensities are checked at top middle and bottom shell of the plate and displacement evolution has been carried out for the same model.

\section{1boundary Conditions}

As the top plate/bottom plate and nozzle is analysed for FEA analysis, which is welded on the edge surface of tube sheet, plug sheet. So the tube sheet and plug sheet with all its surface edges. Hence, the restraint condition of the holes of tube sheet and plug sheet is $U x=0, U z=0, U y=0, R x=R y=R z=0$ 
The header nozzles are connected with pipe lines during operation part from load due to internal pressure, nozzle are subjected to external forces and moments applied simultaneously. It is assumed that the external forces and moments are 2 times of API allowable load for nozzles \& header. For simplicity, analysing at the steady state position simulates the loading of the header.

\subsection{Loading Conditions}

This analysis is based on 2 API loading with internal design pressure.

\begin{tabular}{|l|l|l|l|l|l|l|}
\hline Nozzle size (NPS) & $\begin{array}{l}\text { Moments } \\
\text { Mx }\end{array}$ & $\begin{array}{l}(\mathrm{ft}-\mathrm{lbf}) \\
\mathrm{My}\end{array}$ & $\mathrm{Mz}$ & $\begin{array}{l}\text { Force } \\
\text { Fx }\end{array}$ & $\begin{array}{l}\text { (ibf) } \\
\text { Fy }\end{array}$ & Fz \\
\hline DN 150 & 3160 & 4500 & 2400 & 1800 & 2260 & 2260 \\
\hline
\end{tabular}

Internal Design Pressure : $1200 \mathrm{psi}$

\subsection{Criteria Of Acceptability}

The acceptance criteria are as per ASME VIII, Div. 2.

"Design based on stress analysis".

1. Stress intensity derived from the average value across the thickness of a section of the General Primary Stress $(\mathrm{Pm})$ produced by internal pressure and other loads but excluding geometrical discontinuities and all secondary and peak stresses must be less than $\mathrm{Sm}$; where $\mathrm{Sm}$ is the allowable stress intensity of material at design temperature.

2. Stress intensity derived from the average value across the thickness of a section of the Local Primary Stress (PL) produced by internal pressure and other loads including geometrical discontinuities but excluding all secondary and peak stresses must be less than $1.5 \mathrm{Sm}$.

3. Stress intensity derived from the average value across the thickness of a section of the Local Primary membrane stress plus primary stress proportional to distance from centroid produced only by mechanical load $((\mathrm{PL}+\mathrm{Pb})$ must be less than $1.5 \mathrm{Sm}$.

4. Stress intensity derived from the addition of local primary membrane equivalent stress, secondary bending equivalent stress \& secondary equivalent stress $((\mathrm{PL}+\mathrm{Pb}+\mathrm{Q})$ across the thickness of a section must be less than $3 \mathrm{Sm}$.

\section{Result \& Conclusion}

As per the above code, the stress intensity needs to be checked. The stress intensity ( $\mathrm{Sm})$ is defined as:

Sint $=$ largest absolute value of $\sigma 1-\sigma 2,-\sigma 2-\sigma 3,-\sigma 3-\sigma 1$

Where, $\sigma 1, \sigma 2, \sigma 3$ are the principal stresses.

Also, Sint $=2 \times$ Maximum shear stress.

Since the computer program used in the analysis directly gives the output of maximum shear stress,. However all stress plots are given based on maximum shear stress. All plotted results are in the following units.

\subsection{Result Evaluation}

The stress evaluation is performed as per Appedix-4of ASME Code Section VIII, Div 2,. The primary and primary plus secondary stress intensities are checked within allowable stresses as given in below. The stress evaluation is performed at the regions where maximum stress is expected. From, the ASME Code, Section II, Part D, Table 1A, Appedix-4.

$\mathrm{Sm}=$ Allowable Stress $=19521 \mathrm{psi}$

Evaluation of maximum induced stress intensity during API loads \& pressure:

Stresses are in $\mathbf{N} / \mathbf{m m} 2$

\begin{tabular}{|l|l|l|l|l|}
\hline $\begin{array}{l}\text { Position } \\
\text { Stress Category }\end{array}$ & On HEADER & $\begin{array}{l}\text { Allowable Stress } \\
\text { as per Appx.4 }\end{array}$ & Header & Remark \\
\hline Sint $=$ PL + Q & $\begin{array}{l}2 * \text { Max. Shear } \\
14106 \times 2=28212\end{array}$ & $3 \mathrm{Sm}=58563$ & Top Header(Stationary) & SAFE \\
\hline Sint $=$ PL + Q & $24737 \times 2=49474$ & $3 \mathrm{Sm}=58563$ & $\begin{array}{l}\text { Bottom } \\
\text { Header(Stationary) }\end{array}$ & SAFE \\
\hline Sint $=$ PL + Q & $19434 \times 2=38868$ & $3 \mathrm{Sm}=58563$ & Floating Header & SAFE \\
\hline
\end{tabular}

Following conclusion are drawn from this study-

1) From the FEA analysis it is observed that the header nozzle is free from collapse and serviceability failure.

2) No reinforcement pad is required at nozzle opening, the header nozzle is self reinforced.

3) Actual displacement observed is less than the value in plot generated by the software hence results of the software is acceptable as it gives conservative result. 
4) Results shows that check of structural integrity can be carried out by FEA software in better way since for large opening proof test to be carried out, which is time consuming and costly affair.

\section{References}

[1]. www.Google.com

[2]. www.wikipedia.org

[3]. www.geiind.com

[4]. David Heckman, Davis, Gene Massion, Mark Greise, Finite element analysis of pressure vessels, MBARI, 1998

[5]. Eugene F. Mgyesy, Pressure vessel hand book, pressure vessel handbook publishing Inc., fourth edition, 1978.

[6]. K.satoh, J.Kubota, J.Kashiwakura and S. Maruyama, Structural integrity of heat exchanger component for top entry loop type FB R, Elsevier science publisher,Vol.E, 1993.

[7]. Krishnamurthy CS ,Finite element analysis 2nd ed. Tata Mc-Graw Hill Book Company ,New Delhi, 1994.

[8]. David Heckman, Davis, Gene Massion, Mark Greise, Finite element analysis of pressure vessels, MBARI, 1998.

[9]. J.Chattopadhyay, H.S.Kushwaha and E.Roos ,Some recent developments on integrity assessment of pipes and elbows, Int. J. of solids and structure,Vol.43,Issue 10,pp 2904-2931, 2006.

[10]. 15th Australasian Fluid Mechanics Conference, Sizing of air-cooled heat exchanger, 2005

[11]. M. T. Gonzalez; N. C. Petracci; M. J. Urbicain, Air cooled heat exchanger design using successive quadratic programming, J. of Heat transfer engineering, Vol22, Issue 3, pages $11-16,2001$

[12]. P.Chellapandi, A Biswas, S.C.Chetal, S,B.Bhoje ,Theoretical and experimental assessment of structure integrity of primary pipe,IAEA-TECDOC,2003.

[13]. Z.F.Sang ,Y.J.Lin, L.P.Xue\& G.E.O. Widera, Limit and Burst Pressures for a Cylindrical Vessel With a 30 deg-Lateral (d/D $\$$ 0.5), J. of Pressure Vessel Technol. ,Vol127,Issue1,pp 61-70,2005.

[14]. Yong Wan Kim, Dong Ok Kim, Jae Seon Lee, Suhn Choi and Sung QuunZee, Thermo-mechanical simulation for nozzle header of once-through steam generator by experiment and finite element method Int. J. of pressure vessel and piping, Vol. 82, Issue 8, Pages 602-609, 2005

[15]. ASME (American Society of Mechanical Engineers) code sec VIII Div-I Edition 2004 Addenda 2006.

[16]. ASME (American Society of Mechanical Engineers) code sec VIII Div-II Edition 2004 Addenda 2006

[17]. API (American Petroleum Institute) 661 for air cooled heat exchanger, Edition 2006.

[18]. Raymond K. Yee and Mike Kapper, A Structural Integrity Assessment Methodology for Pressurized Vessels, J. Pressure Vessel Technol. Vol 128, Issue 4, 541 (6 pages), 2006

[19]. Dong Stelling ,FEA Analysis of a Large Nozzle to cylinder shell Junction, Carmagen Engineering, Inc.2008. 